\title{
Antimicrobial Activity of Five Yemeni Medicinal Plants against Selected Human Pathogenic Bacteria and Fungi
}

\author{
Nagi Al-Haj*, Alariqi Reem, Hassan Al-Shamahy, Khaled Al-Moyed, Saleh S. Bahaj, Ammar Jaber \\ Dept. of Medical Microbiology, Faculty of Medicine and Health Sciences, Sana’a, University, Sana'a, Yemen \\ Email: ^naji2005@gmail.com
}

How to cite this paper: Al-Haj, N., Reem, A., Al-Shamahy, H., Al-Moyed, K., Bahaj, S.S. and Jaber, A. (2019) Antimicrobial Activity of Five Yemeni Medicinal Plants against Selected Human Pathogenic Bacteria and Fungi. American Journal of Plant Sciences, 10, 1699-1707. https://doi.org/10.4236/ajps.2019.1010121

Received: September 8, 2019

Accepted: October 5, 2019

Published: October 8, 2019

Copyright @ 2019 by author(s) and Scientific Research Publishing Inc. This work is licensed under the Creative Commons Attribution International License (CC BY 4.0).

http://creativecommons.org/licenses/by/4.0/ c) (i) Open Access

\begin{abstract}
Background: The emergence and spread of antibiotic resistance, as well as the evolution of new strains of disease causing agents, are of great concern to the global health community. Nowadays, reports have indicated that many of healthcare-associated, antimicrobial-resistant bacteria are not only multidrug resistant pathogens but also broadly drug-resistant and pandrug-resistant bacteria. Objective: This study is focused on exploring the antimicrobial properties of five different plants that are commonly being used as traditional medicines in Yemen against Gram positive, Gram negative bacteria and fungi. Methods: The antimicrobial potential of five different plant extracts was screened against selected human pathogenic bacteria and fungi. Methanolic extracts of Dodonaea viscose, Plantago lanceolata, Withania samnifera, Pulicaria crispa, and Rumex nervosus were subjected to a test of their antimicrobial properties by Modified Agar Diffusion and Minimum Inhibitory Concentration. Results: The results indicated that all the five plants extract showed antibacterial activity against a selected microorganism at a concentration of $60 \mathrm{mg} / \mathrm{ml}$. The highest potential was observed in the extract of $W$. somnifera against $S$. taphyloccocus aureus, Pseudomonas aeruginosa, Proteus miarbilis and Candida albicans with zone of inhibition of $23 \mathrm{~mm}, 20.7 \mathrm{~mm}$, $20 \mathrm{~mm}$ and $25.3 \mathrm{~mm}$, respectively. $R$. nervosus also showed the highest MIC against test organisms. Only two medicinal plant Pulicaria crispa, and Rumex nervosus extracts showed non antifungal activity. Conclusion: The experiment confirmed the efficacy of some selected plant extracts as natural antimicrobial and can be potential sources for the synthesis of antibacterial drugs.
\end{abstract}

\section{Keywords}

Antimicrobial Activity, Plant Extract, Multidrug Resistant, Yemen 


\section{Introduction}

Antimicrobial agents are essentially important in reducing the global burden of infectious diseases [1]. However, emergence and dissemination of multidrug resistant (MDR) strain in pathogenic bacteria have become a significant public health threat as there are fewer, or even sometimes no, effective antimicrobial agents available for the infection caused by pathogenic bacteria [2] [3]. Thus, in the light of the evidence of the rapid global spread of resistant clinical isolates, the need to find new antimicrobial agents is of paramount importance. However, the past record of rapid, widespread emergence of resistance to newly introduced antimicrobial agents indicates that even new families of antimicrobial agents will have a short life expectancy [4] [5].

Plants that possess therapeutic properties or exert beneficial pharmacological effects on the human body are generally known as medicinal plants. A vast number of medicinal plants have been recognized as valuable resources of natural antimicrobial compounds as an alternative that can potentially be effective in the treatment of these problematic bacterial infections [6]. According to the World Health Organization (WHO), medicinal plants would be the best source to obtain a variety of drugs [7]. Antimicrobial compounds of plant origin may occur in stems, roots, leaves, bark, flowers and fruits of plants. Plants derived phytoalexin, sothiocynates, allicins, anthocyanins and essential oils, tannins and polyphenols and terpenoids have demonstrated antibacterial and/or antifungal activities. These compounds are bactericidal and/or bacteriostatic inducing lag time, growth rate and maximum growth of microorganisms [8]. A number of phytotherapy manuals have mentioned various medicinal plants for treating infectious diseases as urinary tract infections, gastrointestinal disorders, respiratory disease, and cutaneous infections. The revolutionized therapy of infectious diseases by the use of antimicrobial drugs has certain limitations due to changing patterns of resistance in pathogens and side effects they produced. These limitations demand improved pharmacokinetic properties, which necessitate continued research for new antimicrobial compounds for the development of drugs [9]. There have been a number of reports of antibacterial activity from natural resources [10] and special attention has been reported for antibacterial and/or antifungal activities related to natural product against several pathogens. People of Yemen have been using many plant species as traditional medicines long ago, including treatment of infectious diseases, but there has been relatively scanty data regarding their in vivo and in vitro efficacy. Considering the vast potentiality of plants as sources for antimicrobial drugs, this study aimed to investigate the antibacterial and antifungal activity extracts of some selected medicinal plants from different location in Yemen against selected MDR pathogens.

\section{Materials and Methods}

\subsection{Sample Collection}

Five different plants were collected from different locations in Yemen and iden- 
tified by Pharmacognosist from faculty Pharmacy, Sana'a University. As shown in Table 1 the local name, family, parts used, and, location and traditionally uses.

Table 1. Medicinal plants tested for their antibacterial activity in the study.

\begin{tabular}{|c|c|c|c|c|c|}
\hline $\begin{array}{l}\text { Botanical } \\
\text { Name }\end{array}$ & Local name & Family & Part used & $\begin{array}{l}\text { Site of } \\
\text { collection }\end{array}$ & Traditional uses \\
\hline $\begin{array}{l}\text { Dodonaea } \\
\text { viscose }\end{array}$ & $\begin{array}{l}\text { Shahth } \\
\text {,sahs }\end{array}$ & Sapindaceae & L Leaves & Ibb-baadan & $\begin{array}{l}\text { Used to treat wounds, } \\
\text { burns and cuts, rheumatism, } \\
\text { anti fever and for gut } \\
\text { inflammation, headaches, } \\
\text { backaches stomach pain, } \\
\text { pils and simple ulcer }\end{array}$ \\
\hline $\begin{array}{l}\text { Plantago } \\
\text { lanceolata }\end{array}$ & qerdaa & Plantaginacea & Leaves & Ibb-baadan & $\begin{array}{l}\text { Used in many beverages (e.g. } \\
\text { Bio ALP T ea by Val plants) } \\
\text { and even tarts }\end{array}$ \\
\hline $\begin{array}{l}\text { Withania } \\
\text { somnifera }\end{array}$ & Abaab & Solanaceae & All plant & Ibb-baadan & $\begin{array}{l}\text { Used to treat nervous } \\
\text { disorders, intestinal } \\
\text { infections and leprosy. }\end{array}$ \\
\hline $\begin{array}{l}\text { Rumex } \\
\text { nervosus }\end{array}$ & Othrab & Polygonaceae & Leaves & Ibb-baadan & $\begin{array}{l}\text { Used as a diuretic and } \\
\text { laxative, toothache and guts } \\
\text { inflammation }\end{array}$ \\
\hline $\begin{array}{l}\text { Pulicaria } \\
\text { crispa }\end{array}$ & $\begin{array}{l}\text { koaa, ensif. } \\
\text { Mashmoom }\end{array}$ & Compositae & Leaves & Al-Mahweet & $\begin{array}{l}\text { Used for breathing; heart } \\
\text { disease. }\end{array}$ \\
\hline
\end{tabular}

\subsection{Preparation of Plant Extracts}

The extraction of plants was done adopting the method of [10] [11] with slight modifications. The collected samples were first washed under running tap water to remove dust particles and then divided into two parts: leaf and whole plant then air-dried in shade at room temperature for two weeks. Using a home grinder, the plant parts were then ground to fine powder. The weight of the ground powder was taken and the extract of each plant was prepared by using a cold percolation method. Two hundred and fifty gram of fine powder from each plant was dissolved in $150 \mathrm{ml}$ of $99.9 \%$ methanol $\left(\mathrm{CH}_{3} \mathrm{OH}\right)$ (Fisher Scientific, Germany) at room temperature for five successive days. The supernatant was filtered through Whatman filter paper No. 1 (GE Healthcare Whatman ${ }^{\mathrm{mix}}$, USA) while the residues were used for a second and third extraction. Each day the dissolved parts were filtered and stored in a glass bottle. After the third extraction, the filtrates were then evaporated under reduced pressure at $60^{\circ} \mathrm{C}$ using a rotary evaporator to yield the crude extract. The crude extract was collected in a vial covered with aluminium foil to protect the extract from direct sunlight and were kept in bottle at $4^{\circ} \mathrm{C}$ for further use.

\subsection{Bacterial and Fungal Strains}

Four selected human pathogenic bacteria and fungi were obtained from National Center Of Public Health Laboratories, Sana'a Yemen and two reference strain, $S$. aureus, P. aeruginosa, P. miarbilis, C.albicans, Escherichia coli ATCC 25922 and 
S. aureus ATCC 25923. A series of morphological, physiological, and conventional biochemical tests were performed to identify the selected microorganisms [12]. The fungi were identified following growth on selective Sabouraud Dextrose Agar media (SDA) (HiMedia, Mumbai, India) followed by morphological and microscopic characteristics. Antimicrobial susceptibility test was performed for all microbial isolates by modified Kirby Bauer disc diffusion method following the Clinical and Laboratory Standards Institute (CLSI) guideline. Multidrug resistant (MDR) isolates were defined as those isolates that are resistant to three classes of antibiotics [13].

\subsection{Disk Diffusion Assay}

The antimicrobial susceptibility was initially assayed by the agar disk diffusion method [13] on the Mueller Hinton Agar (MHA) plates (Oxoid.UK). $60 \mathrm{mg} / \mathrm{ml}$ concentration of each plant extract were prepared in 10\% in DMSO (Dimethyl Sulfoxide) (Sigma-Aldrich, Germany). The selected human pathogenic bacteria and fungi cell suspensions were adjusted to $0.5 \mathrm{McF}$ arland turbidity standards to prepare $1 \times 10^{8} \mathrm{bacterial} / \mathrm{ml}$ inoculum. Each bacterial suspension was inoculated on Mueller-Hinton agar plates, and the plates were then allowed to dry for 5 minutes. The sterile filter paper disks (Whatman No. 1, diameter $=6 \mathrm{~mm}$ ) were soaked in $10 \mu \mathrm{l}$ of each plant extract. The extract-soaked filter paper disks were then placed on the inoculated Mueller-Hinton agar plates. Cefotaxime $(30 \mu \mathrm{g})$ disk was used as the positive control, and 10\% DMSO-soaked filter paper disk was used as the negative control. Plates were incubated for $18 \mathrm{hr}$ at $35^{\circ} \mathrm{C} \pm 2^{\circ} \mathrm{C}$. After incubation, the zones of inhibition were recorded as the diameter of the growth-free zones measured in $\mathrm{mm}$ using a sterile cork-borer $(6 \mathrm{~mm}$ ) (Difco, Becton-Dickson, Sparks, MD, USA).

\subsection{Minimum Inhibitory Concentration (MIC)}

Plant extracts that gave a positive result for the disk diffusion assay were used to determine MIC using the microplate dilution method [13]. Serial 2-fold dilutions of the plant extracts were prepared in the 10\% DMSO DMSO (Dimethyl Sulfoxide) (Sigma-Aldrich, Germany), yielding a final concentration of $5 \times 10^{5}$ $\mathrm{CFU} / \mathrm{mL}$ in each well. Inoculum of organism was prepared in Mueller-Hinton broth (Oxoid.UK)., and the turbidity was adjusted to approximately $0.5 \mathrm{McFar}$ land turbidity standard to prepare $1 \times 10^{8}$ bacterial $/ \mathrm{ml} .250 \mu \mathrm{l}$ of plant extract was added to each well of the 96-well microplate. $50 \mu \mathrm{l}$ of bacterial suspension was added to each well except the negative controls. Amikacin drug was used as the positive control. 10\% DMSO and plant extracts without bacterial suspension were used as the negative controls. Microtiter plates were incubated at $35^{\circ} \mathrm{C} \pm$ $2^{\circ} \mathrm{C}$ for $24 \mathrm{hr}$. After incubation, plates were observed for the formation of a clear zone around the well which corresponds to the antimicrobial activity of tested compounds. The zone of inhibition (ZOI) was observed and measured in $\mathrm{mm}$. 


\subsection{Data Analysis Method}

All experiments were independently repeated three times. Data were analysed and calculated within EXCEL (Microsoft Office 2016, Microsoft, USA).

\section{Results}

\subsection{Percent of Methanol Extraction}

The highest percent was obtained from $W$. somnifera extract of $16.5 \%$ while the least yield was of $P$. crispa Table 2 .

Table 2. Ppercentages of methanolic extract used in the study.

\begin{tabular}{ccc}
\hline Plants & Solvent used & (\%) Extract \\
\hline Dodonaea Viscose & Methanol & 11.3 \\
Plantago lanceolata & Methanol & 8.5 \\
Withania somnifera & Methanol & 16.5 \\
Rumex nervosus & Methanol & 7.0 \\
Pulicaria crispa & Methanol & 5.3 \\
\hline
\end{tabular}

Evaluation of the antimicrobial activity of five different plant extracts was determined initially by the disc diffusion method against different microorganisms. These organisms were frequently encountered in infectious diseases. The study showed that all plant extracts used in the study exhibited a varying degree of antimicrobial activity against all microorganisms tested Table 3.

Table 3. Diameter of zones of inhibition $(\mathrm{mm})$ of plant extracts against microorganisms at $60 \mathrm{mg} / \mathrm{ml}$ concentration.

\begin{tabular}{|c|c|c|c|c|c|}
\hline \multirow{2}{*}{$\begin{array}{c}\text { Test } \\
\text { organism }\end{array}$} & \multicolumn{5}{|c|}{ Plant extract } \\
\hline & D. viscose & iceolat & W. somnifera & P. crispa & $R$. nervosus \\
\hline S. aureus & $16.30 \pm 0.96$ & $13.60 \pm 1.1$ & $23.00 \pm 1.4$ & $12.30 \pm 1.2$ & $13.30 \pm 0.57$ \\
\hline$P$. aeruginosa & $11.50 \pm 1.52$ & $18.00 \pm 1.5$ & $20.00 \pm 7.7$ & $10.60 \pm 0.58$ & $18.60 \pm 0.58$ \\
\hline P. mirabilis & - & - & $20.00 \pm 1.2$ & - & $22.30 \pm 0.6$ \\
\hline C. albicans & $12.60 \pm 0.58$ & $15.60 \pm 2.0$ & $25.30 \pm 0.57$ & - & - \\
\hline E. coli ATCC 25922 & 13.0 & - & 15 & 10 & - \\
\hline $\begin{array}{c}S . \text { aureus } A T C C \\
25923\end{array}$ & 11 & - & 15 & - & - \\
\hline
\end{tabular}

It was observed that $W$. somnifera was the most effective among the five plant extracts tested. It showed a zone of inhibition (ZOI) against all gram negative, Gram positive bacteria and fungi. $P$. crispa was found to be less effective against Gram negative bacteria and fungi. The extract from $P$. lanceolat showed ZOI against $S$. aureus as well as $P$. eruginosa but no effecting on $P$. mirabilis and $C$. albicans. The extract from R. nervosus showed ZOI against $S$. aureus, $P$. aeruginosa and $P$. mirabilis but no effecting on $C$. albicans. While, W. somnifera and 
$R$. nervosus showed antibacterial activity against gram negative bacteria $P$. mirabilis only. The highest Antifungal activity was shown only by $W$. somnifera, against $C$. albicans in compare to non antifungal effecting of palnt extract $P$. crispa and $R$. nervosus.

The effectiveness of the extracts in tested bacterial strains was determined by measuring the minimum inhibitory concentration (MIC). MIC was performed for only those organisms which showed a zone of inhibition and were sensitive to the plant extracts in the previous antimicrobial assay by agar well diffusion method. Among all plant extracts tested, was found to show strong antimicrobial activity. The MIC of $W$. somnifera extract against $S$. aureus and $C$. albican were $5 \mathrm{mg} / \mathrm{ml}$ but with $P$. aeruginosa and $P$. mirabilis were $10 \mathrm{mg} / \mathrm{ml}$ (Table 4).

Table 4. MIC value of plant extracts against microorganisms $(\mathrm{mg} / \mathrm{mL})$.

\begin{tabular}{cccccc}
\hline \multirow{2}{*}{$\begin{array}{c}\text { Test } \\
\text { organism }\end{array}$} & D. viscose & P. lanceolat & W. somnifera & P.crispa & R. nervosus \\
\cline { 2 - 5 } & $20 \mathrm{mg} / \mathrm{ml}$ & $20 \mathrm{mg} / \mathrm{ml}$ & $5 \mathrm{mg} / \mathrm{ml}$ & $40 \mathrm{mg} / \mathrm{ml}$ & $10 \mathrm{mg} / \mathrm{ml}$ \\
S. aureus & $40 \mathrm{mg} / \mathrm{ml}$ & $20 \mathrm{mg} / \mathrm{ml}$ & $10 \mathrm{mg} / \mathrm{ml}$ & $40 \mathrm{mg} / \mathrm{ml}$ & $10 \mathrm{mg} / \mathrm{ml}$ \\
$P$. aeruginosa & $60 \mathrm{mg} / \mathrm{ml}$ & $60 \mathrm{mg} / \mathrm{ml}$ & $10 \mathrm{mg} / \mathrm{ml}$ & $60 \mathrm{mg} / \mathrm{ml}$ & $5 \mathrm{mg} / \mathrm{ml}$ \\
$\begin{array}{c}\text { P. } \text { mirabilis } \\
\text { C. albicans }\end{array}$ & $40 \mathrm{mg} / \mathrm{ml}$ & $20 \mathrm{mg} / \mathrm{ml}$ & $5 \mathrm{mg} / \mathrm{ml}$ & $60 \mathrm{mg} / \mathrm{ml}$ & $80 \mathrm{mg} / \mathrm{ml}$ \\
\hline
\end{tabular}

\section{Discussion}

Antibiotic resistance is a problem that continues to challenge the healthcare sector in a large part of the world in both developing and developed countries. The emergence and spread of multidrug resistant pathogens have substantially threatened the current antibacterial therapy. This has necessitated a search for a new source of antimicrobial substances such as plants as they produce a variety of bioactive compounds of known therapeutic properties [2] [14] [15]. This study has been conducted to evaluate the antimicrobial activity of different medicinal plant extracts against human pathogens including two reference strains using methanol extracts of five different plants collected from different area in Yemen for this study. Although some extracts exhibited a good antibacterial activity towards different tested bacterial isolates, many plant extracts exhibited a limited antibacterial activity against the test bacterial isolates as judged by their MIC values. The plant extract of current study such as $W$. somnifera was very active against $S$. aureus, $P$. aeruginosa, $P$. mirabilis and $C$. albicans. the result finding was not similar with study from Jordan which found the plant $P$. lanceolata was not active against $C$. albicans and the variation in quality or composition of the same plant species could be made the difference due to difference in the environmental condition and genetic variation [16]. When we compared previous reported from Ethiopia, it was found that $D$. viscose exhibited activity against $S$. aureus p. erogenousa and $C$. albicans [17]. While reported from $\mathrm{Pa}$ kistan showed effective antibacterial activity against $S$. aureus. $R$. nervosus 
showed inhibited effect on Bacteria of Gram positive and Gram negative of $\mathcal{S}$. aureus, $P$. aerugenosa and $P$. mirabilis with no effect on $C$. albicans at the concentration $(60 \mathrm{mg} / \mathrm{ml})$, this is agreed with reported from Ethiopia and Saudi Arabia against $S$. aureus and $P$. aeruginosa and $S$. pyogenes respectively and disagreed with antimicrobial activity against $C$. albicans [17] [18]. The plant extract of $W$. somnifera showed the highest effect against $S$. aureus, $P$. aeruginosa, $P$. mirabilis and $C$. albicans this agreed with previous report from Yemen [19] while the extract of $P$. crispa it was least antibacteri active only active against $S$. aureus, $P$. aeruginosa, but no effect on $P$. mirabilis and $C$. albicans this finding disagreed with reported from Somalia [20].

\section{Conclusion}

The results obtained from this study provided evidence for the methanol extracts of the Yemeni traditional medicinal plants. Methanolic extracts of Dodonaea viscose, Plantago lanceolata, Withania samnifera, Pulicaria crispa, and Rumex nervosus exhibited beneficial antibacterial activity against Gram positive, Gram negative and fungi. The highest antimicrobial activity was observed for methanol extract of $W$. somnifera which showed a MIC value in the stronger in the range than positive control used. It can be concluded that a low polar active compound present in $W$. somnifera extract may be responsible for the significant antimicrobial activity. Further scientific evaluation of these plants should be done including fractionation and further characterization of phytochemicals to identify the active components responsible for the antimicrobial activity, as well as to adjudge the in vivo activities of these constituents.

\section{Conflicts of Interest}

The authors declare no conflicts of interest regarding the publication of this paper.

\section{References}

[1] Bhatia, R. and Narain, J.P. (2010) The Growing Challenge of Antimicrobial Resistance in the South-East Asia Region-Are We Losing the Battle? Indian Journal of Medical Research, 132, 482-486.

[2] Boucher, H.W., Talbot, G.H., Bradley, J.S., Edwards Jr., J.E., Gilbert, D., Rice, L.B., Scheld, M., Spellberg, B. and Bartlett, J. (2009) Bad Bugs, No Drugs: No ESKAPE! An Update from the Infectious Diseases Society of America. Clinical Infectious Diseases, 48, 1-12. https://doi.org/10.1086/595011

[3] Giamarellou. H. (2010) Multidrug-Resistant Gram-Negative Bacteria: How to Treat and for How Long. International Journal of Antimicrobial Agents, 36, S50-S54. https://doi.org/10.1016/j.ijantimicag.2010.11.014

[4] Coates, A., Hu, Y., Bax, R. and Page, C. (2002) The Future Challenges Facing the Development of New Antimicrobial Drugs. Nature Reviews Drug Discovery, 1, 895-910. https://doi.org/10.1038/nrd940

[5] Marasini, B.P., Baral, P., Aryal, P., Ghimire, K.R., Neupane, S., Dahal, N., Singh, A., Ghimire, L. and Shrestha, K. (2015) Evaluation of Antibacterial Activity of Some 
Traditionally Used Medicinal Plants against Human Pathogenic Bacteria. BioMed Research International, 2015, Article ID: 265425. https://doi.org/10.1155/2015/265425

[6] Iwu, M.W., Dunca, A.R. and Okunji, C.O. (1999) New Antimicrobials of Plant Origin in. Perspectives on New Crops and New Uses. In: Janick, J., Ed., Plant Breeding Reviews, ASHS Press, Alexandria, VA.

[7] World Health Organization (2002) WHO Traditional Medicine Strategy. Geneva.

[8] Borchardt, R., Wyse, D.L., Sheaffer, C.C., Kauppi, K.L., Fulcher, R.G., Ehlke, N.J., Biesboer, D.D. and Bey, R.F. (2008) Antimicrobial Activity of Native and Naturalized Plants of Minnesota and Wisconsin. Journal of Medicinal Plants Research, 2, 98-110.

[9] Al-Haj, N.A., Mashan, N.I. and Shamudin, M.N. (2009) Antibacterial Activity in Marine Algae Eucheuma denticulatum against Staphylococcus aureus and Streptococcus pyogenes. Research Journal of Biological Sciences, 4, 519-524.

[10] AL-Haj, N.A., Mashan, N.I., Mariana, N., Shamsudin, M.N., Mohamad, H., Vairappan, C.S. and Sekawi, Z. (2010) Antibacterial Activity of Marine Source Extracts Against Multidrug Resistance Organisms. American Journal of Pharmacology and Toxicology, 5, 95-102. https://doi.org/10.3844/ajptsp.2010.95.102

[11] Al-Haj, N.A., Hassan, K.Z., Alabed, A.A.A., Al Mahdi, A.Y., Abdsalam, R. and Albawani, S.M (2018) Antibacterial Assays of Malaysian Medicinal Plant Polygonum minus Using Different Extraction Methods. Research Journal of Medical Sciences, 12, 5-11.

[12] Mindy, P., Ajello, G., Bopp, C., Elliott, J., Facklam, R., et al. (2003) Manual for the Laboratory Identification and Antimicrobial Susceptibility Testing of Bacterial Pathogens of Public Health Importance in the Developing World. CDC and WHO, $1-383$.

[13] National Committee for Clinical Laboratory Standards (1997) Performance Standards for Antimicrobial Disk Susceptibility Tests. 6th Edition, Approved Standard M2-A6 (M100-S7). National Committee for Clinical Laboratory Standards, Wayne, PA.

[14] Romero, C.D., Chopin, S.F., Buck, G., Martinez, E., Garcia, M. and Bixby, L. (2005) Antibacterial Properties of Common Herbal Remedies of the Southwest. Journal of Ethnopharmacology, 99, 253-257. https://doi.org/10.1016/j.jep.2005.02.028

[15] Talbot, G.H., Bradley, J., Edwards Jr., J.E., Gilbert, D., Scheld, M. and Bartlett, J.G. (2006) Bad Bugs Need Drugs: An Update on the Development Pipeline from the Antimicrobial Availability Task Force of the Infectious Diseases Society of America. Clinical Infectious Diseases, 42, 657-668. https://doi.org/10.1086/499819

[16] Hassawi, D. and Kharma, A. (2006) Antimicrobial Activity of Some Medicinal Plants against Candida Albicans. Journal of Biological Science, 6, 112-113.

[17] Getie, M., Gebre-Mariam, T., Rietz, R., Höhne, C., Huschka, C., Schmidtke, M., Abate, A. and Neubert, R.H. (2003) Evaluation of Anti Microbial and Anti Inflammatory Activities of Medicinal Plants Dodonaea viscosa, Rumex nervosus, Rumex obyssinicus. Fitoterapia, 74, 139-143. https://doi.org/10.1016/S0367-326X(02)00315-5

[18] Al Gamedy, E. (2007) Studies on Juniperus excelsa and Rumex nervosus and Their Effects on Some Microorganisms. King Abdulaziz University, Makkah, Saudi Arabia.

[19] Ali, N.A., Jülich, W.D., Kusnick, C. and Lindequist, U. (2001) Screening of Yemeni Medicinal Plants for Antibacterial and Cytotoxic Activities. Journal of Ethnopharmacology, 74, 173-179. https://doi.org/10.1016/S0378-8741(00)00364-0 
[20] Foudah, A.I., Alam, A., Soliman, G.A., Salkini, M.A., Ibnouf Ahmed, E.O. and Yusufoglu, H.S. (2016) Pharmacognostical, Antibacterial and Antioxidant Studies of Aerial Parts of Pulicaria somalensis (Family: Asteraceae). Asian Journal of Biological Sciences, 9, 19-26. https://doi.org/10.3923/ajbs.2016.19.26 